\title{
Fisheries oceanography and the ecology of early life histories of fishes: a perspective over fifty years
}

\author{
JOHN JEFFREY GOVONI \\ United States Department of Commerce, National Oceanic and Atmospheric Administration, National Ocean Service, \\ Center for Coastal Fisheries and Habitat Research, 101 Pivers Island Road, Beaufort, NC, USA. \\ E-mail: Jeff.Govoni@noaa.gov
}

\begin{abstract}
SUMMARY: Fisheries oceanography can be defined as the study of the ecology of fishes in the ocean: so defined, it comprises study at all levels of ecological organization-organisms, populations, communities, and ecosystems. The early life history of fishes plays out at each of these levels of organization. A paradigm developed by Johan Hjort at the turn of the twentieth century, along with postulates by Hjort and many of his colleagues that followed, came to guide much of fisheries oceanography through the ensuing hundred years. Research themes that address these postulates can be roughly partitioned as the study of the physiological ecology of the eggs and larvae of fishes in the sea, and the study of the abundance and distribution of fish propagules. Using case studies of organisms and physical processes, considerable progress has been made in understanding the causes of variation in population recruitment, defined either by stage-based models and simulated by individual-based models. Some of this progress has been published in Scientia Marina, or its predecessor Investigación Pesquera. The causes of variation, however, are interactive and operative at differing, yet often overlapping, spatial and temporal scales. Difficulty in matching spatial scales that typically differ by an order of magnitude or more, will continue to trouble the resolution of causes of population recruitment. Moreover, study of the causes of variation in recruitment has not led to predictive power at an annual scale. Prediction at a decadal scale, using community (or more appropriately larval fish assemblages) and ecosystem level dynamics, is more hopeful.
\end{abstract}

Keywords: fishery oceanography, fish early life history.

RESUMEN: LA OCEANOGRAFÍA PESQUERA Y LA ECOLOGÍA DE LOS PRIMEROS ESTADIOS DE DESARROLLO DE LOS PECES: UNA PERSPECTIVA DE CINCUENTA AÑOS. - La oceanografía pesquera puede ser definida como la ecología de los peces en el océano: definida de este modo, comprende el estudio a todos los niveles de organización ecológica: organismos, poblaciones, comunidades y ecosistemas. Los primeros estadios de desarrollo de los peces intervienen en cada uno de estos niveles de organización. El paradigma desarrollado por Johan Hjort a principio de siglo veinte, junto con postulados posteriores del propio Hjort y muchos de sus colegas, han servido de guía de la oceanografía pesquera de los siguientes cien años. Los temas de investigación a que conducen estos postulados pueden ser fundamentalmente divididos en el estudio de la ecología fisiológica de los huevos y larvas de peces en el mar y el estudio de la distribución y abundancia de los propágulos. Utilizando el estudio de casos particulares de organismos, se han conseguido considerables progresos en la comprensión de las causas de variación en el reclutamiento de las poblaciones, definido ya sea por los modelos basados en el estadio de desarrollo o en simulaciones basadas en el individuo. Algunos de estos avances han sido publicados en Scientia Marina, o en su predecesora Investigación Pesquera. No obstante, las causas de variación son interactivas y operativas a escalas espaciales y temporales distintas, o incluso solapadas. La dificultad para ajustar las escalas espaciales que típicamente difieren uno o más órdenes de magnitud, continuarán dificultando la resolución de las causas del reclutamiento de las poblaciones. Además, el estudio de las causas de variación en el reclutamiento no ha alcanzado un poder de predicción a escala anual. La predicción a escala de décadas utilizando las comunidades (o más apropiadamente los agrupamientos de larvas de peces) y la dinámica de los diversos niveles de los ecosistemas, es más esperanzadora.

Palabras clave: oceanografía pesquera, primeros estadios de desarrollo de peces. 


\section{INTRODUCTION}

As a branch of ecology, fisheries oceanography operates at all of the levels of ecological organization: the organismal (Dayton and Sala, 2001), population (Cushing, 1996), community (Reynolds, 2001), and ecosystem levels (Steele, 1974). At each of these levels, the life histories of fishes plays out (Fuiman and Werner, 2002; Watanabe et al., 1996; and references therein). Early life history stages of fishes (eggs, larvae, and juveniles) must survive, or at least a few must survive, and be recruited to sustain populations through time (Rothschild, 1986; Rothschild, 2000). Populations of fishes compose communities, and ecosystems comprise all other levels of ecological organization (Frank and Leggett, 1994).

The advancement of ecological thought, and fisheries oceanography, in the $20^{\text {th }}$ century can be divided in pre- and post World War II periods. Ecology advanced markedly in the pre-World War II period with the establishment of basic ecological principles (e.g. Golley, 2001). In the post-World War II era, ecology has been preoccupied with attempted synthesis and with a search for unification of these principles. Throughout, fisheries oceanography has dealt with organismal life histories, population ecology, and ecological communities. Though variation in populations of fishes was recognized as a problem at the turn of the last century, the last 50 years have seen a focus on the highly variable nature of population recruitment (Chambers and Trippel, 1997; and references therein) with the hope that an understanding of the factors that contribute to variability could be used as a tool of fisheries management (e.g. Link, 2002). With the realization and renewed appreciation that single populations operate within ecosystems, with the failure of attempts to manage fisheries on the basis of single populations (for maximum sustainable yield, etc.), and with the lack of political will to implement regulation (both national and international (e.g. Bissix and Rees, 2001)), fisheries management has turned attention to the highest level of ecological organization, the ecosystem (e.g. Browman and Stergiou, 2004; and references therein).

Since the founding of Investigación Pesquera in 1955, through the transition to Scientia Marina in 1988 , fisheries oceanography and the early life history of fishes has been a frequent topic of publication. A plea for basic ecological research and for fisheries oceanography (albeit specifically for phytoplankton and primary production, but ramifying

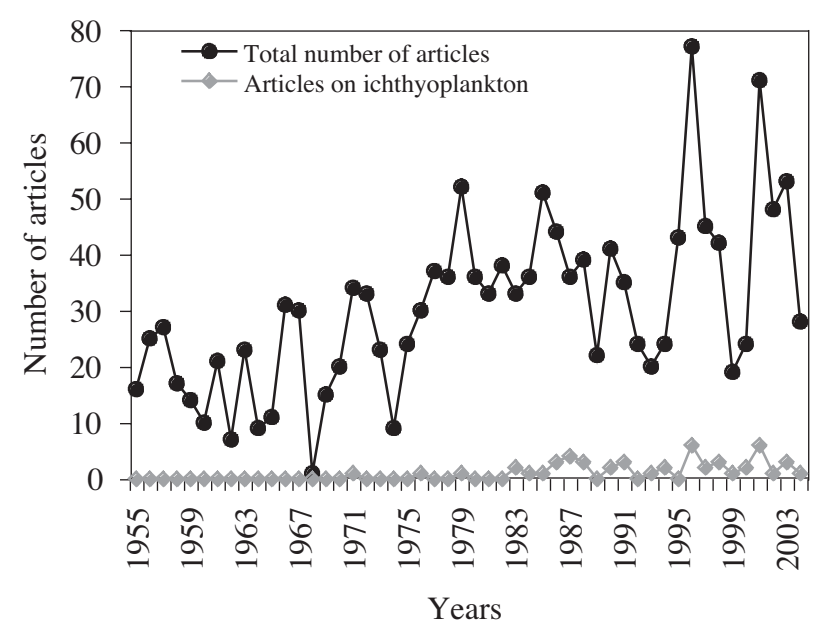

FIG. 1 - Publications on ichthyoplankton in Scientia Marina or its predecessor Investigación Pesquera versus the total number of papers published by these journals.

into considerations of plant and animal succession, diversity, population abundance, and ecosystem management) was articulated by Ramón Margalef in an essay entitled "The study of pelagic ecosystems" that appeared in the book "Perspectives in ecological theory" (Margalef, 1968). Some of this synthesis was predicated upon detailed work published in the Journal. The publication of articles on fishery oceanography and ichthyoplankton in Scientia Marina rose to a high of 14 in 1996 when Scientia Marina published a total of 77 articles on all topics of marine science (Fig. 1). Electronic, on-line searches would reveal a similar rise in the number of publications on some aspects of fisheries oceanography and early life histories of fishes in other topical journals over this time period.

This essay offers a perspective on fisheries oceanography and the role played by the early life history stages of fishes in that endeavor. This essay is neither a comprehensive nor exhaustive literature review. The body of literature on this topic is now voluminous. Numerous review articles, theme sections within journals, or supplementary issues of journals (many in Scientia Marina), and books chronicle the history of fisheries oceanography and the role of the early life history of fishes in fisheries oceanography. This essay references these reviews, along with papers that are seminal or that mark junctures in thought, or that are more recent or not otherwise referenced. This essay recognizes the population recruitment paradigm broached by Johan Hjort (1914) as the impetus for research and partitions research themes around the postulates that sprang from Hjort's paradigm. These postulates are 
roughly classified as physiological ecology of larval fishes (including feeding success, growth, and predation) and the study of the abundance and distribution of fish eggs and larvae in the ocean as influenced by physical advection. This essay also presents some personal observations of issues and some insights into accomplishments, and offers an outlook for future research.

\section{HJORT'S PARADIGM}

At the turn of the twentieth century, Johan Hjort developed a paradigm that attempted to explain the recruitment of young fishes to adult populations (Hjort, 1914); this paradigm set the course for a century of follow-up work. Hjort's recruitment paradigm held that variation of fish populations depended upon varying survival of year classes of fishes through the first year of life (e.g. Chambers and Trippel, 1997; and references therein). Hjort, and his colleagues, followed by attempting to assign variation into two principal causes of mortality of fish larvae: the abundance, or complete lack of, appropriate food, which varies spatially and temporally; and variation in population integrity, which varied through the physical advection of fish propagules to areas favorable, or unfavorable, for development and survival. The first postulate of Hjort's paradigm, success at first feeding, was to drive much of fisheries oceanography through most of the twentieth century (e.g. Lasker, 1981a). The second postulate, that advection disperses or simply transports fish propagules away from, or to, areas favorable for survival, has attracted renewed interest in the postWorld War II era, and has been further elaborated more recently as the member/vagrant hypothesis (Sinclair, 1988).

The research directed to Hjort's paradigm has been largely two pronged: (1) laboratory experimental and field study of the physiological ecology, especially trophic ecology, of fish eggs, larvae, and juveniles (e.g. Hunter, 1981; Blaxter, 1988); and (2) study of the abundance and distribution of fish propagules in the ocean (Kendall and Duker, 1998).

\section{PHYSIOLOGICAL ECOLOGY}

Physiological ecology is defined as an examination of functional processes that enable an organism to meet environmental challenges. This organismal level work is essential to establish relationships that are otherwise purely correlative from the observation of animals in the field alone. Observation of the influence of the environment on the physiology of young fishes in the ocean is difficult, and realistic conditions are difficult to simulate in the laboratory, either ship- board or ashore. Because of the artificiality of laboratory environments, experiments must be coupled with observation of physiological response in the sea; hence, physiological ecology. The question of how young fishes function and how they survive in the sea has been an important and sustained thrust of fisheries oceanography (e.g. Geffen et al., 1997; and references therein). In regard to Hjort's paradigm, the research effort has been primarily directed toward feeding and growth of larval fishes, and secondarily to the avoidance of predators.

\section{Feeding success of fish larvae}

\section{Issues}

Acquisition, digestion, and assimilation of food are physiological processes that are enmeshed within the ecology of any animal. The first postulate to follow Hjort's paradigm, that the lack of suitable food constitutes a major hurdle for first-feeding fishes and consequently their recruitment, still lacks complete and unequivocal empirical proof from the sea. Three principal causes of recruitment failure have been recognized: the match, or mismatch, of larval fish abundance and an abundance of food for larvae; a stable-ocean that effects the match of fish larvae and their food in the vertical dimension; and small scale turbulence that enhances the rate of encounter of fish larvae and their food.

Match or mismatch, first articulated by Cushing (e.g. Shepherd and Cushing, 1990), is predicated on the premise that annual cycles in primary production and subsequent secondary production either match, or does not match, reproductive cycles of fishes, such that the abundance of appropriate (in terms of size as well as nutritional value) food sources coincide temporally with initial feeding of larval fishes. Many case studies have evolved from this original hypothesis (Cushing, 1996; and references therein).

Subsequently, Lasker (1981b) hypothesized that coincidence of appropriate food and first-feeding fish larvae was key to the survival through early life history stages, but that the coincidence was in the spatial, specifically the vertical, dimension. Lasker 
hypothesized that it was the coincidence of the chlorophyll maximum layer and first-feeding fish larvae that resulted in survival. When wind forces the destruction of the chlorophyll maximum layer, through vertical mixing, the initial feeding of larvae, and subsequent population recruitment, fails.

In opposition to water column stability and the coincidence of larval fishes and their prey, turbulence, i.e. small-scale vertical mixing of water, might erase spatial segregation of planktonic prey and feeding fish larvae, and increase the probability of encounter. First postulated by Rothschild and Osborn (1996), considerable modeling effort and some empirical investigation in the laboratory and in the sea have followed.

\section{Insight and outlook}

In the 1970's there was an apparent disparity between estimates of the ration requirements of larval fishes reared in the laboratory (Houde, 1978) and observations of the concentration of food particles in the sea (e.g. Owen, 1989). This disparity resulted from an over-estimation of the amount of food required for larval fishes, along with the recognition of our inability to accurately detect smallscale concentrations of phyto- and zooplankton appropriate as larval fish food in the sea. The disparity has been partially resolved by the results of physiological energetic experiments (e.g. Kamler, 1992; Wieser, 1995) and the construction of energy budgets for fish larvae that estimate energy requirements and compare these requirements to energy availability (Houde, 1994).

The presence or absence of adequate food and the rate of encounter, are irrelevant to the growth and survival of young fishes unless they can detect, capture, digest, and assimilate this food. This contingency has given rise to intensive laboratory experimentation that attempted to simulate feeding conditions as they exist in the sea. In the 1970 's, the speculation was that the larvae of many marine fishes that live in the pelagia were inadequately developed, in terms of their form and function, to be completely successful in the acquisition of energy from a patchily distributed food supply (Fuiman, 1996; Govoni, 2004a). It now appears that while fish larvae are developing organisms, and that development is a continuum until the completion of metamorphosis, the larvae of marine fishes living in the pelagia are capable of performing the requisite physiological func- tions to the extent necessary to survive, even though they may lack completely developed sensory, locomotive (escape and capture), and digestive systems (Govoni, 2004b).

Match-mismatch is predicated upon primary and secondary production cycles. Translating primary production, through secondary production, to fisheries production has in itself proven problematic (e.g. Nixon, 1988; Houde and Rutherford, 1993; Nielson and Richardson, 1996), in part because of the varying and complex food webs of the pelagia (e.g. Greve and Parsons, 1977; Olsen et al., 2001; Biktashev et al., 2003; but also see Pomeroy, 2001). Moreover, it is apparently new primary production, not primary production in toto, that comes into play in the match-mismatch postulate (Richardson, 2002).

Among taxa of fishes, batch spawning (Hunter et al., 1993; and references therein) and bet hedging (e.g. Roff, 1981) largely ameliorate the effects of mismatch. By distributing propagules through time periods that lapse production cycles, fishes can improve the probability of the survival of their larvae.

The match-mismatch of food for larval fishes and first feeding larvae is controlled physically, by temperature as well as wind-driven mixing (e.g. Alcaraz et al., 2002). Temperature, along with photoperiod, controls spawning physiologically, while wind-driven mixing effects the depth of the upper mixed layer, which typically encompasses the euphotic zone, the zone of primary production. The food of larval fishes, largely the proceeds of secondary production, lives within the upper-mixed layer. Partly because temperature, photoperiod, and wind-driven mixing are seasonally variable, and partly because the modes of primary and secondary production lag or are offset temporally in temperate and boreal zones, match-mismatch finds verification largely in the cool-temperate and boreal ocean (e.g. Beaugrand et al., 2003). Match-mismatch is more difficult to assess in the warm-temperate and tropical ocean that lacks this offset.

Starvation in the sea (either because of matchmismatch or simply low food densities) is not well documented at large spatial scales, though patches of larvae in poor condition are evident (e.g. O'Connell, 1980; Amara and Galois, 2001). Many currently unanswered questions arise from this lack of direct evidence at spatial scales large enough to influence population recruitment. Are condition factors thus far proposed for the assessment of nutri- 
tional state appropriate measures (Ferron and Leggett, 1994)? Morphometric and histopathological measures can be misleading, inasmuch as skewed morphometric ratios (e.g. Powell et al., 1990; Grșnkjaer and Sand, 2003), and histopathological lesions (e.g. Green and McCormick, 1999; Gisbert et al., 2004) can arise by other causes in addition to poor feeding: over eating for example (Mobin et al., 2000)! The use of other indicies of condition, including biochemical composition, metabolic enzyme titer (e.g. Browman and Skiftesvik, 2003; and references therein), and RNA/DNA ratios (e.g. Buckley et al., 1999; Clemmensen et al., 1996) has increased in recent years. As an index of protein synthesis, RNA/DNA ratios integrate the varied physiological factors that contribute to growth (e.g. Høie et al., 1999; Fukuda et al., 2001; Gwak and Tanaka, 2002). RNA/DNA ratios, then, measure growth potential (Weber et al., 2003); but on what time scale of response? How synchronous are changes in biochemical composition, enzyme titer, or RNA/DNA ratios with changes in daily ration or the nutritional content of food? The answers are required before these indices can resolve the nutritional condition of larval fishes at operative spatial and temporal scales.

More work that directly links indices of nutritional condition to oceanographic processes and population level variation is clearly warranted. In addition to it's direct effect on survival, nutritional condition also influences the buoyancy of larval fishes, which in turn affects vertical distribution (Sclafani et al., 1997). Position in the water column can determine coincidence, or lack of coincidence with food. While condition may be linked to season or to water column stratification (e.g. Bergeron, 2000; Kimura et al., 2000; Catalán et al., 2004), the linkage of condition to population level variation in abundance has proven more difficult (e.g. Pepin, et al., 1999), especially at large spatial scales (Megrey and Hinckley, 2001).

Lasker's postulate of ocean stability was specific for the chlorophyll maximum layer that was, in the study area examined (the California Current Region), populated by naked dinoflagellates. Eating dinoflagellates in substantial and nutritionally significant numbers is restricted largely to the larvae of clupeiform fishes (e.g. Govoni et al., 1983). The larval of other fishes eat dinoflagellates incidentally; dinoflagellates are not their critical first food. While zooplankton, as a whole, is often stratified (e.g. Peterson, 1998), layers of dinoflagellates, compo- nents of the microplankton, are not of the same spatial scale as layers of zooplankton.

The coincidence in time and space of planktonic food and fish larvae at first feeding, or larval fishes after yolk absorption, depends upon scale, temporal and spatial (Visser and MacKenzie, 1998). In the horizontal dimension, the scales are in the order of weeks, months, and kilometers: in the vertical they are smaller, days, hours, minutes, meters, and centimeters. Too much turbulence erases concentrations of larval fish food, and can diminish encounters between phyto- and zooplankton food, and larval fishes (MacKenzie and Kiørboe, 2000; Fiksen and MacKenzie, 2002; Reiss et al., 2002). The key may lie in the distribution of patches of larvae in time and space (e.g. Dower et al., 1998; Incze et al., 2001).

Recent modeling efforts emphasize the problem of relative scales in resolving the effects of turbulence on larval fish feeding (Galbraith et al., 2004). Turbulence increases net energy gain primarily at low turbulent velocities, $<10 \mathrm{~mm} \mathrm{~s}^{-1}$, and principally for larval fishes that search for food in spherical or hemispherical volumes. The larvae of most fishes, however, search a wedge shaped volume of water and the affects of turbulence are to be expected at much lower velocities, $5 \mathrm{~mm} \mathrm{~s}^{-1}$.

Larval fishes frequently have empty guts when collected at sea, irrespective of the time of day when they are collected. Is this the result of stress-induced defecation owing to handling in the net or preservation, or is it an indication of either individual variation in feeding activity within a patch of larvae or an indication of a poor feeding environment? The answer may lie in comparisons of the feeding response of larvae in the sea when prey fields are adequately quantified, and laboratory studies where prey fields are controlled. Examination of the contents of the guts of larval fishes indicates that they are highly selective feeders. Even larvae within the same family that occupy the same parcel of water and that share nearly identical morphology, and sensory and locomotive capabilities, eat significantly different food organisms (Govoni et al., 1986b). Apparent selectivity, however, might simply mean that fish larvae are only able to perceive and capture specific food organisms. Consequently, food of appropriate size, shape, and swimming behavior, not simply food of adequate abundance, is necessary. Resolution of this question is essential for improved accuracy of predictions of the physiological energetic requirements of larval fishes, as well as for considerations of the coincidence of larval fishes and their food. 
Fish larvae eat some zooplanktonic organisms that leave little digestive residue in their alimentary canals. As a consequence, alimentary canals appear empty, or are filled with an unrecognizable slurry of chyme. Among the organisms that may account for this unidentifiable chyme are the aloricate protozoans, only recently recognized from laboratory experiments as potentially import constituents of larval fish diets (Hunt von Herbing and Gallager, 2000; Hunt von Herbing et al., 2001). Protozoans in the guts of larvae collected in the sea have been recently identified (Fukami et al., 1999), but a thorough assessment of their importance as dietary constituents awaits further study.

Much of the theory of population recruitment of fishes is predicated upon density dependence, so if larval fishes are capable of diminishing their food supply, they will compound density-dependent mortality owing to inadequate food supply. Gut content load is a required parameter estimate for the calculation of daily rations of larval fishes. It is also the parameter used to develop energy budgets that can be used, in turn, to assess the exploitation of food supplies. Do larval fish impact zooplankton populations? Probably not because estimates of the daily rations of larval fishes indicate that the amount of food required is insufficient to reduce zooplankton populations and there is a difference of an order of magnitude in abundance of larval fishes and of their zooplanktonic food (Dagg and Govoni, 1996; Nielsen and Munk, 1998; Pepin and Penny, 2000). A lingering problem in the determination of daily rations, however, is the correct mathematical form of evacuation rate of larval fishes (Govoni et al., 1986a). The mathematical form of evacuation rate is the subject of argument even for adult fishes (e.g. Jumars, 2000; Andersen, 2001; Bochdansky and Deibel, 2001); it has not been resolved for larval fishes.

\section{Growth of larval fishes}

Issues

The growth of larval fishes is central to the estimation of population recruitment (e.g. Beyer, 1989). Growth is a rate process and it is a physiological integrator of all energy spent in osmoregulation and dissipated through friction (heat) in metabolism and locomotion, and energy ingested, digested, and assimilated. As a rate, growth requires the dimension of time. The discovery of a means of the deter- mining age of larval fishes at an appropriate temporal scale, i.e., days, by counting daily increments on otoliths (e.g. Jones, 1986; Campana, 2001), resulted in a explosion of research and consequent information about growth in early life. The age of larval fishes caught in the ocean and verified by spawning and rearing larval fishes in the laboratory is now obtainable. As a result, the rate of early growth, heretofore assumed to be allometric, is now empirically resolved for a large phylogenetic array of fishes. Further, growth has now been intrinsically scaled with metabolism (e.g. Finn et al., 2002; Osse and Van den Boogaart, 2004).

\section{Insight nd outlook}

That rapid growth is essential for survival of larval fishes, because it shortens the time that fish larvae spend vulnerable to predators, is subject to debate. Does rapid growth equate to better survival (e.g. Suthers, 1998; Leggett and Deblois, 1994)? Clearly, larval fishes either grow or they die (Anderson, 1988; Sogard, 1997; Nielsen and Munk, 2004). Some inroads into the link between larval fish growth and population variation have been established through the use of the mortality-growth quotient (Houde, 1997), but more work aimed at establishing a link between accelerated growth and population recruitment is warranted. Fishes are highly diverse and they spawn in many different ecosystems worldwide (e.g. Sponaugle and Pinkard, 2004). Categorical statements about rapid growth for all taxa and all ecosystems are subject to skepticism.

Larval fishes collected in the ocean are survivors; presumably small and weak larvae perish through predation (e.g. Heath and Gallego, 1997; Leggett and Deblois, 1994). Larval fishes raised in the laboratory are not subject to predation, unless they are cannibalistic, and some taxa are (e.g. Manica, 2002; Takasuka et al., 2004; and references therein). Yet, runts and brutes simultaneously arise in the laboratory. Growth is a quantitatively inheritable characteristic. As such, variation among individuals may not have simplistic solutions. Moreover, estimates of growth rate determined from fishes collected at sea and those raised in the laboratory are not likely to conform. Coupling these differing growth rates is necessary to fully resolve the connection between growth and mortality (Chambers and Trippel, 1997).

Larval fish change diets as they grow, often before metamorphosis when diets change markedly. 
Coupling changes in diet, with accelerations or decelerations in growth rate (e.g. Kaji et al., 1999; Govoni et al., 2003) is another area for fruitful research that will aid in the resolution of growth and mortality.

\section{Predation}

Issues

While not explicitly indicated by Hjort and his colleagues as a cause of variation in recruitment, predation on larval fishes is relevant to the food in the sea question; fish larvae must eat to grow and they must grow to better escape predators (Bailey and Houde, 1989). So what eats fish eggs and larvae? Almost everything is a predator; from some other larval fishes, to myriad components of the zooplankton, to filter feeding adult fishes (e.g. Takasuka et al., 2004). Because of their size, shape, and swimming capacities, larval fishes are extremely vulnerable.

\section{Insight and outlook}

Sensory perception and locomotor agility that enable predator avoidance, seem adequate defenses for most planktonic predators (Govoni, 2004b). There is no adequate defense for larger predators, i.e., fishes that attack at rapid speed or through suction or filter feeding (e.g. Connell, 2000; and references therein).

The question of what eats larval fishes and, more importantly, how many are eaten remains incompletely resolved. Larval fishes, with little ossified bone, are digested rapidly and leave little residue in the guts of predator. The question of what eats larval fishes might be resolved by immunochemical or molecular-probe approaches to identifying food organisms in the guts of predators. (These techniques should also prove useful in identifying unrecognizable food in the guts of fish larvae, e.g. aloricate protozoans).

So much of the work on predation has been correlative, i.e., correlations between the numbers of predators and prey. Correlations assess the association between or among variables: correlations do not describe functional relationships. Predation, therefore, cannot be appropriately inferred from the presence or absence, or abundance, of predators and prey where there is co-occurrence; predators and prey might simply be segregated in space, com- pletely, or partially with overlapping distributions. There is a growing body of evidence that links predation to variation in year classes (Paradis and Pepin, 2001; Tsou and Collie, 2001; Munk, 2002), but direct verification, i.e., the establishment of cause and effect, remains necessary.

\section{ABUNDANCE AND DISTRIBUTION OF FISH EGGS AND LARVAE IN THE OCEAN}

Describing the abundance and distribution of fish propagules in the ocean is basic fisheries oceanography (Heath, 1992; Kendall and Duker, 1998), and it is essential to the second element of Hjort's paradigm (e.g. Bradbury and Snelgrove, 2001; Dalley et al., 2002; Olivar et al., 2003). Quite simply the advective transport of fish eggs and larvae influences abundance and distribution and provides the mechanism that drives population retention or dispersal of fish eggs and larvae (e.g. Boehlert and Mundy 1994; Hare et al., 2002). Advection also influences the structure of communities, or more properly assemblages (e.g. Smith and Suthers, 1999; Hinrichsen et al., 2003). Many fishes release eggs into the pelagia, typically in the upper $200 \mathrm{~m}$ (e.g. Olivar and Sabatés, 1997), where they are more susceptible to collection than are adult fishes that can avoid mid-water trawls or seek protection from bottom trawls in benthic substrates. The consequence is that surveys of planktonic larvae often reveal more diversity in the fish fauna, than do surveys of juveniles and adults (e.g. Shackell and Frank, 2000; Norberg, 2004). Accurately assessing diversity of the pelagia is the key to understanding ecosystem structure and function and is best done with surveys of fish eggs and larvae (Ahlstrom, 1965).

There are always species of larval fishes in the plankton, though total abundance varies seasonally. Fishes spawn in relation to primary and secondary production cycles, and as a consequence, the abundance of ichthyoplankton typically varies seasonally, except, perhaps, in the tropics where production is annually periodic. Larval fishes, by definition, are part of the meroplankton; species are not constant members of plankton communities. As with so many concepts in ecology, community level organization and the definition of an ecological community, have been the subject of debate. By whatever definition, method of statistical identification (e.g. Miller, 2002), or mechanism of control of organization (e.g. Drake, 1991), ichthyoplankton comprises 
species assemblages (e.g. Moser and Smith, 1993; Gray and Miskiewicz, 2000; Harris and Cyrus, 2000; Doyle et al., 2002; Munk et al., 2004) that vary in time over short periods according to the frequencies of spawning of adult fishes (e.g. Smith $e t$ $a l ., 1999 a)$. In a theoretical sense, multiple populations of larval fishes do not typically constitute an ecological community (but see Acevedo et al., 2002; Munk et al., 2003) that may be in succession toward ecological maturity. Species composition of ichthyoplankton as a whole varies over longer time scales, but this does not owe to ecological succession; it owes, possibly, to ocean climate change (e.g. von Westernhagen et al., 2002).

Documenting the abundance of fish eggs and larvae provides a method of estimating basic population dynamic parameters, including recruitment, that is independent of fishery catch statistics. The most notable of these is the estimation of spawning stock biomass (e.g. Hunter and Lo, 1993; Armstrong et al., 2001). The abundance of older larvae and juveniles is the only fishery independent, empirical estimate of recruitment, though recruitment can be derived retrospectively from daily age determination from otoliths of fishes that survive. With these data, cohorts of larvae can be identified and peaks of cohort abundance possibly linked to year-class success.

Early life histories of fishes have contributed significant advances to population modeling, specifically to models of variation in recruitment, with individually-based models and stage-based models (Chambers and Trippel, 1997).

\section{Insight and outlook}

Deriving basic population dynamic parameters from estimates of the kinds and abundance of fish eggs and larvae is fraught with methodological difficulties. For estimates of spawning stock biomass, population fecundity must be known, and this is complicated by the complex reproductive biology of many fishes (batch spawning and hermaphroditism, most notably). Estimates of the absolute abundance of fish eggs and larvae are difficult to obtain, given the patchy distribution of ichthyoplankton, which owes in part to advective aggregation and diffusion, as well as the location of spawning. Sorting of ichthyoplankton collections and the taxonomy of fish eggs and larvae is labor intensive and time consuming. The development of rapid egg samplers (e.g. Checkley et al., 1997), optical and video plank- ton recorders (e.g. Herman et al., 2004), and acoustic devices, those deployed in the water column (e.g. Peiper et al., 1990; Thomas and Kirsch, 2000; Miyashita, 2003; Meekan et al., 2003; Ressler and Jochens, 2003) and those moored to the bottom (e.g. Flagg et al., 1994; David et al., 1999), might provide partial solutions to these problems, though the technology requires further refinement. (These technological advances, along with satellite-borne remote sensors (e.g. Santos, 2000; Ibelings et al., 2003) will also help solve the problems of the coincidence of larval fishes, their prey, and their predators). Taxonomic verification from net collections by visual examination will, however, always be necessary.

Ecosystem based management of fish populations, was suggested early-on by Walford (1956), yet interest in this approach is now renewed (e.g. Loreau, 2000; Pitcher, 2001; Link, 2002). This renewed interest moves fisheries management away from attention to single populations of single species, to the management of higher levels of ecological organization: communities (or assemblages of larval fishes) and ecosystems (Ulltang, 2003; Beaugrand, 2004). The feature problem with ecosystem management is in definition: how do we define an ecosystem in a pragmatic sense and what parameters are to be measured to provide definition (e.g. Alverson, 2004); where are ecosystem boundaries (Cadenasso et al., 2003)?

Frontal zones can provide physical definition to otherwise apparently homogenous pelagic space and thereby aid in the definition of ecosystems (e.g. Brandt and Wadley, 1981). By definition, fronts are boundaries between water masses (e.g. Olson et al., 1994). Water masses contain communities of zooplankton and assemblages of fish eggs and larvae. Fronts are also where the ecological action is (e.g. the edge affect). They are places where zooplankton, and fish eggs and larvae, can be physically aggregated (e.g. Bjorkstedt et al., 2002).

Eddies can help define pelagic habitats within ecosystems (e.g. Margalef, 2001). Eddies provide the physical mechanisms that might contribute to or deter from population integrity (e.g. Cowen et al., 2000; Paris and Cowen, 2004). Fish propagules can be wafted away from local populations by physical processes within or around eddies, or they can be retained by these same processes, depending upon their vertical position in the water column and the horizontal spatial scale of the eddy (e.g. Hare et al., 1999; Reiss et al., 2000; Allain et al., 2001; Loger- 
well and Smith, 2001). The surface of an understanding of the influence of eddies and fronts, and their inherent physical processes, on population recruitment has only recently been scratched.

A century of intensive investigation into singular causes of year-class variation has not yielded appreciable predictive power over annual periods. While variation has pattern, sources, and consequences (Chambers and Trippel, 1997), annual variation is difficult, if not impossible, to predict. The principal recognized causes (feeding success, predation, and advection) are interactive and each has enough inherent variability to make the prediction of recruitment almost hopeless. The key then is to characterize this variability adequately, to accept it as an inherent characteristic of fish populations, and to build models that make predictions over longer periods (Rice, 1999). Longer term (decade) prediction is more hopeful, since it may be linked to ecological regime shifts (e.g. Bax, 1998; Steele, 1998) that are driven by ocean-climate change (Alheit and Hagen, 1997; Hoffman and Powell, 1998; Dambacher et al., 2002; Richardson and Schoeman, 2004). Decadescale variation, and prediction, requires a broader ecosystem approach (e.g. Miller and Cornuelle, 1999; Pörtner et al., 2001; Bissix and Rees, 2001; Pitcher, 2001; Dambacker et al., 2002; Pedersen et al., 2003; Robinson and Frid, 2003). This approach, and its inclusion of early life histories of fishes, will likely be one of the future directions of fisheries oceanography (Dower et al., 2000).

\section{SUMMARY}

Guided in part by Hjort's hypothesis, fisheries oceanography as directed at population recruitment has made progress in understanding the causes of fluctuations of year-classes of fishes, fluctuations that owe to survival or mortality of eggs and larvae. The principal, currently recognized causes of fluctuation are interactive and the operative mechanisms work at differing and overlapping spatial and temporal scales. Difficulty in matching scales that typically differ by orders of magnitude (e.g. Haury et al., 1977) will persist. Much more work toward achieving the appropriate matches in scale remains to be done. Advances in the technology of electronic, in situ, sensing devices and in satellite borne remote sensors hold promise. These devices will facilitate and accelerate data collection at synoptic scales.
Present progress in understanding has not led to a gain of predictive power. Prediction over annual scales remains unaccomplished, in part, because data acquisition is costly and labor intensive to the point were the lag in acquisition precludes annual prediction. Again, technological advances in data acquisition should shorten the lag. But, immense annual variation seems to be an inherent characteristic of fish populations.

Gaining predictive power over decadal scales is more hopeful, given an understanding of what drives regime shifts within ecosystems. Predicting or forecasting changes in ecosystems, including regime changes that affect exploitable populations, is a current thrust (Clark et al., 2001), and an endeavor with achievable goals.

\section{ACKNOWLEDGMENTS}

I thank M. Pilar Olivar for the invitation to contribute this essay and for providing statistics on papers published in Investigación Pesquera and Scientia Marina. J.A. Hare, J.V. Merriner, and H.I Browman provided reviews of early drafts and offered valuable comments and suggestions for improvement. Views expressed in this article do not necessarily reflect those of the United States Department of Commerce, National Oceanic and Atmospheric Administration, National Ocean Service. The United States government has the right to retain a nonexclusive, royalty-free license in and to any copyright covering this paper.

\section{REFERENCES}

Acevedo, S., O. Dwane and J.M. Fives. - 2002. The community structure of larval fish populations in an area of the Celtic Sea in 1998. J. Mar. Biol. Assoc., U.K. 82: 641-648.

Ahlstrom, E.H. - 1965. Kinds and abundance of fishes in the California Current region based on egg and larval surveys. $C A L$ COFI Rep., 10: 31-37.

Alcaraz, M., C. Marrasé, F. Peters, L. Arin and A. Malits. - 2002. Effects of turbulence conditions on the balance between production and respiration in marine planktonic communities. Mar. Ecol. Prog. Ser., 242: 63-71.

Alheit, J. and E. Hagen. - 1997. Long-term climate forcing of European herring and sardine populations. Fish. Oceanogr., 6: 130-139.

Allain, G., P. Pettitgas and P. Lazure. - 2001. The influence of mesoscale ocean processes on anchovy (Engraulis encrasicolus) recruitment in the Bay of Biscay estimated with a three-dimensional hydrogynamic mode. Fish. Oceanogr., 10: 151-163.

Alverson, D.L. - 2004. Searching for ecosystem reality -terms and concepts. Bull. Mar. Sci., 4: 639-652.

Amara, R. and R. Galois. - 2004. Nutrional condition of metamorphosing sole: spatial and temporal analyses. J. Fish Biol., 63: 72-88. 
Andersen, N.G. - 2001. A gastric evacuation model for three predatory gadoids and implications of using pooled field data of stomach contents to estimate food rations. J. Fish Biol., 59: 1198-1217.

Anderson, J.T. - 1988. A review of size dependent survival during pre-recruit stages of fishes in relation to recruitment. J. Northw. Atl. Fish. Sci., 8: 55-66.

Armstrong, P., P. Connolly, R.D.M. Nash, M.G. Pawson, E. Alesworth, P.J. Coulahan, M. Dickey-Collas, S.P. Milligan, M.F. O'Neill, P.R. Witthames and L. Woolner. - 2001. An application of the egg production method to estimates spawning biomass of cod (Gadus morhua L.), plaice (Pleuronectes platessa L.) and sole (Solea solea L.) in the Irish Sea. ICES J. Mar. Sci., 58: 183-203.

Bailey, K.M. and E.D. Houde. - 1989. Predation on eggs and larvae of marine fishes and the recruitment problem. Adv. Mar. Biol., 25: $1-83$.

Bax, N.J. - 1998. The significance and prediction of predation in marine fisheries. ICES J. Mar. Sci., 55: 249-255.

Beaugrand, G. - 2004. Monitoring marine plankton ecosystems. I. Description of an ecosystem approach based on plankton indicators. Mar. Ecol. Prog. Ser., 269: 69-81.

Beaugrand, G., K.M. Brander, J.A. Lindley, S. Souissi and P.C. Reid. - 2003. Plankton effect on cod recruitment in the North Sea. Nature, 426: 661-664

Bergeron, J.-P. - 2000. Effects of strong winds on the nutritional condition of anchovy (Engraulis encrasicolus L.) larvae in the Bay of Biscay, Northeast Atlantic, as inferred from an early field application of the DNA/-index. ICES J. Mar. Sci., 57: 249-255.

Beyer, J.E. - 1989. Recruitment stability and survival -simple sizespecific theory with examples from the early life dynamics of marine fish. Dana, 7: 45-147.

Biktashev, V.N. J. Brindley and J.W. Horwood. - 2003. Phytoplankton blooms and fish recruitment rate. J. Plankton Res., 25: 211-33.

Bissix, G. and J.A. Rees. - 2001. Can strategic ecosystem management succeed in multiagency environments? Ecol. Appl., 11: 570-583.

Bjorkstedt, E.R., L.K. Rosenfeld, B.A. Grantham, Y. Shkedy and J. Roughgarden. - 2002. Distributions of larval rockfishes Sebastes spp. across nearshore fronts in a coastal upwelling region. Mar. Ecol. Prog. Ser., 242: 215-228.

Bochdansky, A.B. and D. Deibel. - 2001. Consequences of model specification for the determination of gut evacuation rates: redefining the linear model. Can. J. Fish. Aquat. Sci., 58: 1032-1042.

Boehlert, G.W. and B.C. Mundy. - 1994. Vertical and onshore-offshore distribution patterns of tuna larvae in relation to physical habitat features. Mar. Ecol. Prog. Ser., 107: 1-13.

Blaxter, J.H.S. - 1988. Pattern and variety in development. In: W.S. Hoar and D.J. Randall (eds.), Fish Physiology of developing fish, part A., Eggs and larvae, pp. 1-58. Academic Press, San Diego, California.

Bradbury, I.R. and P.V.R. Snelgrove. - 2001. Contrasting larval transport in demersal fish and benthic invertebrates: the roles of behaviour and advective process in determining spatial pattern. Can. J. Fish. Aquat. Sci., 58: 811-823.

Brandt, S.B. and V.A. Wadley. - 1981. Thermal fronts as ecotones and zoogeographic barriers in marine and freshwater systems. Proc. Ecol. Soc. Aust. 11: 13-26.

Browman, H.I. and A.B. Skiftesvik. - 2003. The big fish bang. proceedings of the $26^{\text {th }}$ annual Larval fish conference. Institute of Marine Research, Bergen, Norway.

Browman, H.I. and K.I. Stergiou -2004. Perspectives on ecosystembased approaches to the management of marine resources. Mar. Ecol. Prog. Ser., 274: 269-303.

Buckley, L., E. Caldarone and T.-L. Ong. - 1999. RNA-DNA ration and other nucleic acid-based indicators for growth and condition of marine fishes. Hydrobiol. 401: 265-277.

Cadenasso, M.L., T.A. Steward, K.C. Pickett, S.S. Weathers, T.L. Benning, M.M. Carreiro and T.E. Dawson. - 2003. An interdisciplinary and synthetic approach to ecological boundaries. BioScience, 53: 717-722.

Campana, S.E. - 2001. Accuracy, precision and quality control in age determination, including a review of the use and abuse of validation methods. J. Fish Biol., 59: 197-242.

Catalán, I.A., I.A. Johnston and M.P. Olivar. - 2004. Seasonal differences in muscle fibre recruitment of pilchard larvae in the north-western Mediterranean. J. Fish Biol., 64: 1605-1615.

Chambers, R.C. and E.A. Trippel. - 1997. Early life history and recruitment: legacy and challenges. In: R.C. Chambers and E.A. Trippel (eds.), Early life history and Recruitment in fish populations, pp. 515-549, Chapman and Hall, London.

Checkley, D.M., P.B. Ortner, R.C. Dotson and D.A. Griffith. 1997. Continuous underway fish egg sampler. Fish. Oceanogr., 6: $58-73$.

Clark, J.S., S.R. Carpenter, M. Barber, S. Collins, A. Dodson, J.A. Foley, D.M. Lodge, M. Pascual, R. Pielke, W. Pizer, C. Pringle, W.V. Reid, K.A. Rose, O. Sala, W.H. Schlesinger, D.H. Wall and D.Wear. - 2001. Ecological Forecasts: an emerging imperative. Science, 293: 657-660.

Clemmensen, C. and T. Doan. - 1996. Does otolith sstructure reflect the nutritional condition of a fish larva? Comparison of otolith structure and biochemical index (DNA/RNA ratio) determined in cod larvae. Mar. Ecol. Prog. Ser. 138: 33-39.

Connell, S.D. - 2000. Is there safety in numbers. OIKOS, 88: 527-532.

Cowen, R.K., K.M.M. Lwiza, S. Sponaugle, C.B. Paris and D.B. Olson. - 2000. Connectivity of marine populations: open or closed? Science, 287: 857-859.

Cushing, D.H. - 1996. Towards a Science of recruitment in fish populations. Ecology Institute, Oldendorf/Luhe, Germany.

Dagg, M.J. and J.J. Govoni. - 1996. Is ichthyoplankton predation an important source of copepod mortality in subtropical coastal waters? Mar. Freshwat. Res., 47: 137-144.

Dalley, E.L., J.T. Anderson and B. de Young. - 2002. Atmospheric forcing, larval drift, and recruitment of capelin (Mallotus villosus). ICES J. Mar. Sci., 59: 929-841.

Dambacker, J.M., H.W. Li and P.A. Rossignol. - 2002. Relevance of community structure in assessing indeterminacy of ecological predictions. Ecology, 83: 1372-1385

David, P.M., O. Guerin-Ancey and J.P. Van Cuyck. - 1999. Acoustic discrimination of two zooplankton species (mysid) at 38 and 120 kHz. Deep-Sea Res. I, 46: 319-333.

Dayton, P.K. and E. Sala. - 2001. Natural history: the sense of wonder, creativity and progress in ecology. Sci. Mar., 65 (Suppl. 2): 199-206.

Dower, J.F., P. Pepin and W.C. Leggett. - - 1998. Enhanced gut fullness and an apparent shift in size selectivity by radiated shanny (Ulvaria subbifurcata) larvae in response to increased turbulence. Can. J. Fish. Aquat. Sci., 55: 128-142.

Dower, J., W. Leggett, and K. Frank. -2000. Commentary: improving fisheries oceanography in the future. In: P.J. Harrison and T.R. Parsons (eds.) Fisheries oceanography: an integrative approach to fisheries ecology and management, pp. 263-281. Blackwell Science. Ltd. Oxford.

Doyle, M.J., K.L. Mier, M.S. Busby and R.D. Brodeur. - 2002. Regional variation in springtime ichthyoplankton assemblages in the northeast Pacific Ocean. Prog. Oceanogr., 53: 247-281.

Drake, J.A. - 1991. Community-assembly mechanics and the structure of an experimental species ensemble. Am. Nat., 137: 1-26.

Ferron, A. and W.C. Leggett. . - 1994. An appraisal of condition measures for marine larvalfish. Adv. Mar. Biol., 30: 217-303.

Fiksen, O. and B.R. MacKenzie. - 2002. Process-based models of feeding and prey selection in larval fish. Mar. Ecol. Prog. Ser. 243: $151-164$.

Finn, R.N., I Rșnnestad, T. Van der Meeren and H.J. Fyhn. - 2002. Fuel and metabolic scaling of Atlantic cod Gadus morhua. Mar. Ecol. Prog. Ser., 293: 217-234

Flagg, C.N., C.D. Wirick and S.L. Smith. - 1994. The interaction of phytoplankton,zooplankton and currents from 15 months of continiuous data in the Mid-Atlantic Bight. Deep-Sea Res. II, 41: 411-435

Frank, K.T. and W.C. Leggett. - 1994. Fisheries ecology in the context of ecological and evolutionary theory. Ann. Rev. Ecol. System., 25: 401-422.

Fuiman, L.A. and R.G. Werner. - 2002. Fisheries science: the unique contributions of early life history stages. Blackwell Science. Ltd. Oxford.

Fuiman, L.A. - 1996. Preface: dynamic morphology, physiology and behaviour of fish larvae. Mar. Freshwat. Behav. Physiol., 28: $1-2$.

Fukami, K., A. Watanabe, S. Fujita, K. Yamaoka and T. Nishijima. - 1999. Predation on naked protozoan microplankton by fish larvae. Mar. Ecol. Prog. Ser., 185: 285-291.

Fukuda, M., H. Sako, T. Shigeta and R. Shibata. - 2001. Relation- 
ships between growth andbiochemical indices in laboratoryreared juvenile Japanese flounder (Paralichthys olivaceus), and its application to wild fish. Mar. Biol., 138: 47-55.

Galbraith, P.S., H.I. Browman, R.G. Racca, A.B. Skiftesvik, and J.F. Saint-Pierre. - 2004. Effect of turbulence on the energetics of foraging in Atlantic cod Gadus morhua larvae.Mar.Ecol. Prog. Ser., 281: 241-257.

Geffen, A.J., J.M. Fives and J.E. Thorpe. - 1997. Ichthyoplankton ecology. The Fisheries Society of the British Isles Annual Symposium. J. Fish Biol., 51 (Suppl. A): 1-430.

Gisbert, E., D.B. Conklin and R.H. Piedrahita. - 2004. Effects of delayed first feeding on the nutritional condition and mortality of California halibut larvae. J. Fish Biol., 64: 116-132.

Golley, F.B. - 2001. Conversaciones con Ramón: big questions for the millennium. Sci. Mar., 65 (Suppl. 2): 73-84.

Govoni, J.J. - 2004a. The development of form and function in fishes and the question of larval adaptation. In: J.J. Govoni (ed.), The development of form and function in fishes and the question of larval adaptation, pp. 195-198. American Fisheries Society Symposium 40, Bethesda, Maryland.

Govoni, J.J. - 2004b. Epilogue. In: J.J. Govoni (ed.), The development of form and function in fishes and the question of larval adaptation, pp. 195-198. American Fisheries Society Symposium 40, Bethesda, Maryland.

Govoni, J.J., D.E. Hoss and A.J. Chester. - 1983. Comparative feeding of three species of larval fishes in the northern Gulf of Mexico: Brevoortia patronus, Leiostomus xanthurus, and Micropogonias undulatus. Mar. Ecol. Prog. Ser., 13: 189-199.

Govoni, J.J., G.W. Boehlert and Y. Watanabe. - 1986a. The physiology of digestion in fish larvae. Environ. Biol. Fish., 16: 59-77.

Govoni, J.J., P.B. Ortner, F. Al-Yamani and L.C. Hill. - 1986b. Selective feeding of spot, Leiostomus xanthurus, and Atlantic croaker, Micropogonias undulatus, larvae in the northern Gulf of Mexico. Mar. Ecol. Prog. Ser., 28: 175-183.

Govoni, J.J., E.H., Laban and J.A. Hare. - 2003. The early life history of swordfish (Xiphias gladius) in the western North Atlantic. Fish. Bull., 101: 778-789.

Gray, C.A. and A.G. Miskiewicz. - 2000. Larval Fish assemblages in South-east Australian coastal waters: seasonal and spatial structure. Estuar. Coast. Shelf Sci., 50: 549-570.

Green, B.S. and M.I. McCormick. - 1999. Influence of larval feeding history on the body condition of Amphiprion melops. J. Fish Biol., 55: 1273-1289.

Greve, W. and T.R. Parsons. - 1977. Photosynthesis and fish production: hypothetical effects of climate change and pollution. Helgol. Wiss. Meeresunters., 30, 666-672.

Grșnkjaer, P. and M.K Sand. - 2003. Fluctuating asymmetry and nutritional condition of Baltic cod (Gadus morhua) larvae. Mar. Biol., 143: 191-197.

Gwak, W.-S. and M. Tanaka. - 2002. Changes in RNA, DNA and protein contents of laboratory-reared Japanese flounder Paralichthys olivaceus during metamorphosis and settlement. Fish. Sci., 68: 27-33.

Hare, J.A., J.A. Quilan, F.E. Werner, B.O. Blanton, J.J. Govoni, R.B. Forward, L.R. Settle and D.E. Hoss. - 1999. Larval transport during winter in the SABRE study area: results of a coupled vertical larval behaviour -three-dimensional circulation model. Fish. Oceanogr., 8 (Suppl. 2), 57-76.

Hare, J.A., J.H. Churchill, R.K. Cowen, T. Berger, P. Cornillon, P. Dragos, S. Glenn, J.J. Govoni and T.N. Lee. - 2002. Routes and rates of larval fish transport from the southeastern to the midAtlantic North American continental shelf. Limnol. Oceanogr. 47: 1774-1789.

Harris, S.A. and D.P. Cyrus. - 2000. Comparison of larval fish assemblages in three large estuarine systems, KwaZulu-Natal, South Africa. Mar. Biol., 137: 527-541.

Haury, L.R., J.A. McGowan and P.H. Wiebe. - 1977. Patterms and processes in the time- space scales of plankton distributions. In J.H. Steele (ed.), Spatial pattern in plankton communities, pp. 277-327. Plenum Press, New York.

Heath, M.R. - 1992. Field Investigations of the early life stages of marine fish. Adv. Mar. Biol., 28: 1-174.

Heath, M. and A. Gallego. - 1997. From the biology of the individual to the dynamics of the population: bridging the gap in fish early life studies. J. Fish Biol., 51 (Suppl. A): 1-29.

Herman, A.W., B. Beanlands and E.F. Phillips. - 2004. The next generation of optical plankton counter: the Laser-OPC. $J$. Plankton Res., 26: 1135-1145.
Hinrichsen, H.-H., A. Lehmann, C. Möllmann and J.O. Schmidt. 2003. Dependency of larval fish survival on retention/dispersion in food limited environments: the Baltic Sea as a case study. Fish. Oceanogr., 12: 425-433.

Hjort, J. - 1914. Fluxuation in the great fisheries of northern Europe viewed in the light of biological research. Rapp. P. -v. Réun. Cons. Perm. Int. Explor. Mer, 20: 1-228.

Hoffman, E.E and T.M. Powell -1998. Environmental variability effects on marine fisheries: four case histories. Ecol. Appl., 8 (Suppl. 1): S23-S32.

Høie, H., A. Folkvord and A. Johannessen. - 1999. The influence of different parental combinations and incubation temperature on the RNA and DNA content of herring larvae at hatching: a pilot study. J. Fish Biol. 55 (Suppl. A): 110-118.

Houde, E.D. - 1978. Critical food concentrations for larvae of three species of subtropical marine fishes. Bull. Mar. Sci., 28: 395-411.

Houde, E.D. - 1994. Differences between marine and freshwater fish larvae: implications for recruitment. ICES J. Mar. Sci., 51: 51-97.

Houde, E.D. - 1997. Patterns and trends in larval-stage growth and mortality of teleost fish. J. Fish Biol., 51 (Suppl. A): 52-83.

Houde, E.D. and E.S. Rutherford. - 1993. Recent trends in estuarine fisheries: predictions of fish production and yield. Estuaries, 16: 161-176.

Hunter von Herbing, I. and S.M. Gallager. - 2000. Foraging behavior in early Atlantic cod larvae (Gadus morhua) feeding on a protozoan (Balanion sp.) And a copepod nauplius (Pseudodiaptomus sp.). Mar. Biol., 136: 591-602.

Hunter von Herbing, I., S.M. Gallager and W. Halteman. - 2001 Metabolic cost of pursuit and attack in early larval Atlantic cod. Mar. Ecol. Prog. Ser., 216: 201-212.

Hunter, J.R. - 1981. Feeding ecology and predation of marine fish larvae. In: R. Lasker (ed.). Marine fish larvae: morphology, ecology, and relation to fishes, pp. 33-77. Washington Sea Grant Program, Seattle.

Hunter, J.R. and N.C.-H. Lo. - 1993. Ichthyoplankton methods for estimating fish biomass introduction and terminology. Bull. Mar. Sci., 53: 723-727.

Ibelings, B.W., M. Vonk, H.F.J. Los, D.T. van der Molen and W.M. Mooij. - 2003. Fuzzy modeling of cyanobacterial surface waterblooms: validation with NOAA-AVHRR satellite images. Ecol. Appl., 13: 1456-1472.

Incze, L.S., D. Hebert, N. Wolff, N. Oakey and D. Dye. - 2001. Changes in copepod distributions associated with increased turbulence from wind stress. Mar. Ecol. Prog. Ser., 213: 229-240.

Jones, C.M. - 1986. Determining age of larval fish with the otolith increment technique. Fish. Bull., 84: 91-104.

Jumars, P.A. - 2000. Animal guts as nonideal chemical reactors: partial mixing and axial variation in absorption kinetics. Am. Nat. 155: 544-555.

Kaji, T.M., M. Tanaka, M. Oka, H. Taccaceae, S. Ohsumi, K. Teruya and J. Hirokawa. - 1999. Growth and morphological development of laboratory-reared yellowfin tuna Thunnus albacares larvae and early juveniles, with special emphasis on the digestive system. Fish. Sci., 65: 700-707.

Kamler, E. - 1992. Early life history of fish: an energetics approach. Chapman and Hall, London.

Kendall, A.J., and Duker, G.J. - 1998. The development of recruitment fisheries oceanography in the United States. Fish. Oceanogr., 7: 69-88.

Kimura, R., Y. Watanabe and H. Zenitani. - 2000. Nutritional condition of first-feeding larvae of Japanese sardine in the coastal and oceanic waters along the Kuroshio Current. ICES J. Mar. Sci., 57: 240-248.

Lasker, R. - 1981a. Marine fish larvae: morphology, ecology, and relation to fishies. Washington Sea Grant Program, Seattle.

Lasker, R. $-1981 \mathrm{~b}$. The role of a stable ocean in larval fish survival and subsequent recruitment. In: R. Lasker (ed.). Marine fish larvae: morphology, ecology, and relation to fisheries, pp. 8087. Washington Sea Grant Program, Seattle.

Leggett, W.C. and E. Deblois. - 1994. Recruitment in marine fishes: is it regulated by starvation and predation in the egg and larval stages? Netherlands J. Sea Res., 32: 1199- 234.

Link, J.S. - 2002. What does ecosystem-based fisheries management mean? Fisheries, 27: 18- 21

Logerwell, E.A. and P.E. Smith. - 2001. Mesoscale eddies and survival of late stage Pacific sardine (Sardinops sagax) larvae. Fish. Oceanogr., 10: 13-25. 
Loreau, M. - 2000. Biodiversity and ecosystem functioning: recent theoretical advances. OIKOS, 91: 3-17.

MacKenzie, B.R. and T. Kiørboe. - 2000. Larval fish feeding and turbulence: a case for the downside. Limnol. Oceanogr., 45: 1-10.

Manica, A. - 2002. Filial cannibalism in teleost fish. Biol. Rev., 77: 261-277.

Margalef, R. - 1968. The study of pelagic ecosystems. In: R. Margalef (ed.), Perspectives in ecological theory, pp. 51-79. Univ. Chicago Press, Chicago.

Margalef, R. - 2001. The top layers of water bodies, a most important although relatively neglected piece of the biosphere plumbing. Sci. Mar., 65 (Suppl. 2): 73-84.

Meekan, M.G., J.H. Carleton, A.D. McKinnon, K. Flynn and M. Furnas. - 2003. What determines the growth of tropical reef fish larvae in the plankton: food or temperature. Mar. Ecol. Prog. Ser., 256: 193-204.

Megrey, B.A. and S. Hinckley. - 2001. Effects of turbulence on feeding of larval fishes: a sensitivity analysis using an individual-based model. ICES J. Mar. Sci., 58: 1015-1029.

Miller, A.J. and B.D. Cornuelle. - 1999. Forecasts from fits of frontal fluctuations. Dyn.

Atmos. Oceans, 29: 305-333.

Miller, T.J. - 1999. Assemblages, communities, and species interactions. In: L.A. Fuiman, and R.G. Werner (eds.) Fisheries science: the unique contributions of early life history stages, $\mathrm{pp}$. 183-205. Blackwell Science. Ltd. Oxford.

Miyashita, K. - 2003. Diurnal changes in the acoustic-frequency characteristics of Japanese anchovy (Engraulis japonicus) postlarvae "shirasu" inferred from theoretical scattering models. ICES J. Mar. Sci., 60: 532-537.

Mobin, S.M.A., K. Kanai and K. Yoshikoshi. - 2000. Histopathological alterations in the digestive system of larval and juvenile Japanese flounder Paralichthys olivaceus reared on four feeding levels. J. Aquat. Anim. Health, 12: 196-208.

Moser, H.G. and P.E. Smith. - 1993. Larval fish assemblages and oceanic boundaries. Bull. Mar. Sci., 53: 283-289.

Munk, P. - 2002. Larval sand lance (Ammodytes sp.) in the diet of small juvenile wolffish (Anarhichas spp.): predatory interactions in frontal water masses off western Greenland. Can. J. Fish. Aquat. Sci. 59: 1759-1767.

Munk, P., B.W. Hansen, T.G. Nielsen and H.A. Thomsen. - 2003. Changes in plankton and fish larvae communities across hydrographic fronts off West Greenland. J. Plankton Res., 25: 815-830.

Munk, P., P.K. Bjşrnsen, P. Boonruang, M. Fryd, P.J. Hansen, V. Janekarn, V. Limtrakulvong, T. G. Nielsen, O.S. Hansen, S. Satapoomin, S. Sawangarreruks, H.A. Thomsen and J.B. Șstergaard. - 2004. Assemblages of fish larvae and mesozooplankton across the continental shelf and shelf slope of the Andaman Sea (NE Indian Ocean). Mar. Ecol. Prog. Ser., 274: 87- 97.

Nielsen, T.G. and P. Munk. - 1998. Zooplankton diversity and the predatory impact by larval and small juvenile fish at the Fisher Banks of the North Sea. J. Plankton Res., 20: 2313-2332.

Nielsen, T.G. and P. Munk. - 2004. Growth pattern and growth dependent mortality of larval and pelagic juvenile North Sea cod Gadus morhua. Mar. Ecol. Prog. Ser., 278: 261-270.

Nielsen, T.G. and K. Richardson. - 1996. Can changes in the fisheries yield in the Kattegat (1950-1992) be linked to changes in primary production? ICES J. Mar. Sci., 53: 988-994.

Nixon, S.W. - 1988. Physical energy inputs and the comparative ecology of lake and marine ecosystems. Limnol. Oceanogr., 33: 1005-1025.

Norberg, J. - 2004. Biodiversity and ecosystem functioning: a complex adaptive systems approach. Limnol. Oceanogr., 49: 12691277.

O'Connell, C.P. - 1980. Percentage of starving northern anchovy, Engraulis mordax, in the sea as estimated by histological methods. Fish. Bull., 78: 475-489.

Olivar, M.P. and A. Sabatés. 1997. Vertical distribution of fish larvae in the north-west Mediterranean Sea in spring. Mar. Biol., 129: 289-300.

Olivar, M.P., I.A. Catalán, M. Emelianov and M.L. Fernández de Puelles. - 2003. Early stages of Sardina pilchardus and environmental anomalies in the Northwestern Mediterranean. Estuar. Coast. Shelf Sci., 56: 609-619.

Olsen, Y., H. Reinertsen, O. Vadstein, T. Andersen, I. Gismervik, C. Duarte, S. Agusti, H. Stibor, U. Sommer, R. Lignell, T. Tamminen, C. Lancelot, V. Rouseau, E. Hoell and K.A. Sanderud.
- 2001. Comparative analysis of food webs based on flow networks: effects of nutrient supply on structure and function of coastal plantkon communities. Cont. Shelf Res., 21: 2043-2053.

Olson, D.B., G.L. Hitchcock, A.J. Mariano, C.J. Ashjian, G. Peng, R.W. Nero and G.P. Podestá. - 1994. Life on the edge: marine life and fronts. Oceanography, 7: 52-60.

Osse, J.W.M. and J.G.M. Van den Boogaart. - 2004. Allometric growth in fish larvae: timing and function. In: J.J. Govoni (ed.), The development of form and function in fishes and the question of larval adaptation, pp. 167-194. American Fisheries Society Symposium 40, Bethesda, Maryland.

Owen, R.W. - 1989. Microscale and finescale variations of small plankton in coastsal and pelagic environments. J. Mar. Res., 47: 197-240.

Paradis, A.R. and P. Pepin. - 2001. Modelling changes in the length-frequency distributions of fish larvae using field estimates of predator abundance and size distributions. Fish. Oceanor., 10: 217-234.

Paris, C.B. and R.K. Cowen. - 2004. Direct evidence of a biophysical retention mechanism for coral reef fish larvae. Limnol. Oceanogr., 49: 1964-1979.

Pedersen, O., D. Slagstad and K.S. Tande. - 2003. Hydrodynamic model forecasts as a guide for process studies on plankton and larval fish. Fish. Oceanogr., 12: 369-380.

Peiper, R.E., D.V. Holliday and G.S. Kleppel. - 1990. Quantitative zooplankton distributions from multifrequency acoustics. $J$. Plankton Res., 12: 433-441.

Pepin, P., G.T. Evans and T.H. Shears. - 1999. Patterns of RNA/DNA ratios in larval fish and their relationship to survival in the field. ICES J. Mar. Sci., 56: 697-706.

Pepin, P. and R. Penny. - 2000. Feeding by a larval fish community: impact on zooplankton. Mar. Ecol. Prog. Ser., 204: 199-212.

Peterson, W.T. - 1998. Life cycles of copepods in upwelling zones. J. Mar. Syst., 15: 313-326.

Pitcher, T.J. - 2001. Fisheries managed to rebuild ecosystems? Reconstructing the past to salvage the future. Ecol. Appl., 11: 601-617.

Pomeroy, L.R. - 2001. Caught in the food web: complexity made simple? Sci. Mar. (Suppl. 2): 31-40.

Pörtner, H.O., B. Berdal, R. Blust, O. Brix, A. Colosimo, B. DeWachter, A. Giuliani, T. Johansen, T. Fischer, R. Knust, G. Lannig, G. Naevdal, A. Nedenes, G. Nyhammer, F.J. Sartoris, I. Serendero, P. Serabella, S. Thorkildsen and M. Zakhartsev. 2001. Climate induced temperature effects on growth performance, fecundity, and recruitment in marine fish: developing a hypothesis for cause and effect relationships in Atlantic cod (Gadus morhua) and common eelpout (Zoarces viviparus). Cont. Shelf Res., 21: 1975-1997.

Powell, A.B., A.J. Chester, J.J. Govoni and S.M. Warlen. - 1990. Nutritional condition of spot larvae associated with the Mississippi River Plume. Trans. Am. Fish. Soc., 119: 957-965.

Reiss, C.S., A. Anis, C.T. Taggart, J.F. Dower and B. Ruddick. 2002. Relationships among vertically structured in situ measures of turbulence, larval fish abundance and feeding success and copepods on Western Bank, Scotian Shelf. Fish. Oceanogr., 11: 156-174.

Reiss, C.S., G. Panteleev, C.T. Taggart, J. Sheng and B. de Young. - 2000. Observations on larval fish transport and retention on the Scotian Shelf in relation to geostrophic circulation. Fish. Oceanogr., 9: 195-213.

Ressler, P.H. and A.E. Jochens. - 2003. Hydrographic and acoustic evidence for enhanced plankton stocks in a small cyclone in the northeastern Gulf of Mexico. Cont. Shelf Res., 23: 41-61.

Reynolds, C.S. - 2001. Emergence in pelagic communities. Sci. Mar., 65 (Suppl. 2): 5-30.

Rice, J.A. - 1999. Coping with uncertainty. Fisheries, 24: 44

Richardson, K. - 2002. Linking plankton and fish production throughout the history of ICES. ICES Mar. Sci. Symp., 215 156-164.

Richardson, A.J. and D.S. Schoeman. - 2004. Climate impact on plankton ecosystems in the northeast Atlantic. Science, 305 1609-1612.

Robinson, L.A. and C.L.J. Frid. - 2003. Dynamic ecosystem models and the evaluation of ecosystem effects of fishing: can we make meaningful predictions? Aquat. Cons: Mar. Freshwat. Ecosyst., 13: 5-20.

Roff, D.A. - 1981. Reproductive uncertainty and the evolution of interoparity: why don't flatfish put all their eggs in one basket? 
Can. J. Fish. Aquat. Sci., 38: 968-977.

Rothschild, B.J. - 1986. Dynamics of marine fish populations. Harvard University Press, Cambridge, Massachusetts,

Rothschild, B.J. - 2000. "Fish stocks and recruitment": the past thrity years. ICES Mar. Sci. Symp., 57: 191-204.

Rothschild, B.J. and T.R. Osborn. - 1996. Small-scale turbulence and plankton contact rates. J. Plankton Res., 10: 465-474.

Santos, A.M. - 2000. Fisheries oceanography using satellite and airborne remote sensing methods: a review. Fish. Res., 49: 1-20.

Sclafani, M., G. Stirling and W.C. Leggett. - 1997. Osmoregulation, nutritional effects and buoyancy of marine larval fish: a bioassy for assessing density changes during the earliest lifehistory stages. Mar. Biol., 129: 1-9.

Shackell, N.L. and K.T. Frank. - 2000. Larval fish diversity on the Scotion shelf. Can. J. Fish. Aquat. Sci., 57: 1747-1760.

Shepherd, J.G. and D.H. Cushing. 1990. -Regulation in fish populations: myth or mirage? Phil. Trans. Roy. Soc. Lond. B, 330: 151-164.

Sinclair, M. - 1988. Marine populations: an essay on population regulation and speciation. Washington Sea Grant Program, University of Washington Press, Seattle.

Smith, K.S., M.T. Gibbs, J.H. Middleton and I.M. Suthers. - 1999a Short-term variability in larval fish assemblages of the Sydney shelf: tracers of hydrographic variability. Mar. Ecol. Prog. Ser., 178: $1-15$.

Smith, K.S. and I.M. Suthers. - 1999. Displacement of diverse ichthyoplankton assemblages by a coastal upwelling event on the Sydney shelf. Mar. Ecol. Prog. Ser., 176: 49-62.

Sogard, S.M. - 1997. Size selective mortality in the juvenile stage of teleost fishes: A review. Bull. Mar. Sci., 60: 1129-1157.

Sponaugle, S. and D.R. Pinkard. - 2004. Impact of variable pelagic environments on natural larval growth and recruitment of the reef fish Thalassoma bifasciatum. J. Fish Biol., 64: 34- 54.

Steele, J.H. - 1974. The structure of marine ecosystems. Harvard University Press.Cambridge, Massachusetts.

Steele, J.H. - 1998. Regime shifts in marine ecosystems. Ecol. Appl., 8: S33-S36.
Suthers, I.M. - 1998. Bigger? Fatter? Or is faster growth better? Considerations on condition in larval and juvenile coral-reef fish. Aust. J. Ecol., 23: 265-273.

Takasuka, A., I. Aoki, and I Mitani. - 2003. Evidence of growthselective predation on larval Japanese anchovy Engraulis japonicus in Isamu Mitani. Mar. Ecol. Prog. Ser., 252: 223-238.

Takasuka, A., Y. Oozeki, R. Kimura, H. Kubota and I. Aoki. - 2004. Growth-selective predation hypothesis revisited for larval anchovy in offshore waters: cannibalism by juveniles versus predation by skipjack tunas. Mar. Ecol. Prog. Ser., 278: 297-301.

Thomas, G.L. and J. Kirsch. - 2000. Nekton and plankton acoustics: an overview. Fish. Oceanogr., 47: 107-113.

Tsou, T.S. and J.S. Collie. - 2001. Predation-mediated recruitment in the Georges Bank fish community. ICES J. Mar. Sci., 58: 994-1001.

Ulltang, S. - 2003. Fish stock assessments and predictions: integrating relevant knowledge. An overview. Sci. Mar., 67 (Suppl.1): 5-12.

von Westernhagen, H., V. Dethlefsen, T. Bade and W. Wosniok. 2002. Species assemblages of pelagic fish embryos in the southern North Sea between 1984 and 2000. Helgol. Mar. Res., 55: 242-251.

Walford, L.A. - 1956. Living resources of the sea: opportunities for research and expansion. Ronald Press. New York.

Watanabe, Y., Y. Yamashita and Y. Oozeki. - 1996. Survival strategies in early life stages of marine resources. Balkema, The Netherlands.

Weber, P.S., P.S. Higgins, R.I. Carlson and D.M. Janz. - 2003 Development and validation of methods for measuring multiple biochemical indices of condition in juvenile fishes. J. Fish Biol., 63: 637-658.

Wieser, W. - 1995. Energetics of fish larvae, the smallest vertebrates. Act. Physiol. Scand., 154: 279-290.

Vissar, A.W. and B.R. MacKenzie. - 1998. Turbulence-induced contact rates of plankton: the question of scale. Mar. Ecol. Prog. Ser., 166: 307-310. 
